20 per cent of all infant mortality; four times more than at the beginning of the century. Similarly, in adult mortality the genetic component is now relatively greater than in the past. These two facts increase the importance of diagnosis, prevention and, in a small number of cases which will gradually increase, treatment. Carter surveys the various aspects of this increased importance of genetic disease and the formidable ethical problems it raises.

On the whole this very readable book is of interest both to the specialist and to the layman. G. Pontecorvo

\section{BIOLOGY UNDER PRESSURE}

High Pressure Effects on Cellular Processes

Edited by A. M. Zimmormann. (Cell Biology: A Series of Monographs.) Pp. xvi +324 . (Academic: New York and London, April 1970). 182s; $\$ 19.50$.

This book has thirteen contributors, including the most distinguished recent investigators in the field, soveral of whom might now be regarded as reaching the peaks of highly productive carcers. Each of the eleven chapters is a separate essay, with an extensive bibliography, but together they form a coherent whole, with author and subject indexes. The book is good value; it is packed with information, is woll illustrated and is interesting to biochemists, physiologists, microbiologists, protozoologists, embryologists and marine scientists.

F. H. Johnson and H. Eyring, drawing on the theories of Arrhcnius and of absolute reaction rates, show how the pressure-temperature relations of bacterial Iuminescence and muscle tension are probably connected with the volume changes involved in enzyme activity and inactivation. J. V. Landau, with full experimental details, similarly explains the effects of pressure on biosynthesis of protein and nucleic acids, and discusses the possibility that protein synthesis requires the maintenance of a gel matrix, which breaks down under prossure. R. Y. Morita and R. R. Becker, citing dilatometric and other relevant studies on enzymes and aqueous systems, point out the difficulties which arise because the effects of prossure are so various and impossible to control experimentally. T. H. Murakami surveys studios in Japan, covering pressure effects on mitosis, nerve and muscle action, coll permeability, oxygen consumption, enzyme inactivation and protein denaturation. C. E. Zobell broadly reviews effects on the morphology and metabolism of micronrganisms.

No bacteria have been found capable of growth at pressures much greater than those in the deep ocean trenches. There are, however, many phyla of marine animals represented at the greatest depths, as $H$. Flugel and C. Schlieper show, and they report further that the tissues of different shallow-water spocies are pre-adapted to varying degrees for functioning at abyssal pressures. Some effects of pressure on freshwater heliozoans, suctorians and ciliates are described by J. A. Kitching, who discusses possible mechanisms of response and adaptation. In another chapter on Protozoa, Solme Zimmerman and A. M. Zimmermann show how earlier studies on the division and movement of cells have been extended to ultrastructural and molecular levels. A. M. Zimmermann contributes another shorter chapter, with T. H. Murakami, on the curious cathodal mlvanotaxis of Tetrahymena, which weakens and eventually reverses if the pressure is increased sufficiently. He goes on to reviow previous and current research on biosynthesis in the eggs of sea urchins. Finally, D. A. Marsland, to whom the volume is dedicated (on or around his seventieth birthday), adds a particularly well organized chapter about the mechanisms involved in cell division. Knowledge of that has advanced considerably as a result of pressure experiments, but for each question tentatively answered, several new ones have arisen.

E. W. KNIGHT-Jones

\section{DIVERSE MICROBES}

\section{The Actinomycetales}

The Jena International Symposium on Taxonomy, September 1968. Edited by H. Prauser. Pp. 439. (Gustav Fischer Verlag: Jena, 1970.) 184s.

Turs book consists of papers presented at a symposium held in September 1968. Although the actinomycetes include microbes of economic importance and attract the attention of a great many workers, a meeting on the scale of this one had not been held for some time. The need for such a publication was therefore considerable.

Treatment of actinomycetes has always reflected the fact that they have affinities with both bacteria and fungi so that thero has been a considerable diversityof taxonomic theory and method applied to the group, which is well illustrated by this collection of papers. Papers by specialists working on most of the best known genera are included, with an understandable exphasis on the most studied Streptomyces genus, although it is somewhat surprising that there is only one paper dealing specifically with the genus Nocardia. There is also a section on methods applied in taxonomy which covers techniques such as infrared spectrophotometry, cell wall analysis, serology and numerical taxonomy. The book is concluded by four papers doaling with taxonomic problems in the Actinomycetales as a whole.

All papers are in English and in spite of occasional inaccuracies the choice of a single language has obvious benefits. Minor misprints are quite frequent and references are given in full in most but not all papers. The standard of production of plates and figures is satisfactory. It may confuse some readers to see the name Actinomyces used in two difforent sonses and it would have been useful to have an indication in all cases when it was used to describe Streptomyces species. There is an index of taxa names but no author or subject index.

To the specialist and non-specialist alike, this is a valuable reference book. The comprehensive range of current views and techniques presented provides an accurate impression of the present state of the taxonomy of this group and should serve as a stimulus for future work. Thus frequent discussions on the "importance" of particular taxonomic characters and the variety of suggested classification schemes illustrate the need for more objective assessments of character value and the purpose of classification schemes. Also, the many new methods providing additional characters may increase confusion if they are not integrated with existing characters in such schemes.

The editor and symposium organizer, Dr H. Prauser, is to be congratulated for providing a much needed review of this topic.

S. T. WILLIAMS

\section{WAR ON WANT}

\section{Evaluation of Novel Protein Products}

Edited by A. E. Bender, R. Kihlberg, B. Löfquist and L. Munck. (Proceedings of the International Biological Programme (IBP) and Wenner-Gren Center Symposiurn held in Stockholm, September 1968.) (Wenner-Gren Center International Symposium Series, Vol. 14.) Pp. viii +390 . (Porgamon: Oxford and Now York, June 1970.) $140 s ; \$ 18.50$.

Thrs book covers proceedings held two years ago in Stockholm. Two years later, the Third Intcrnational Congress of Food Science and Technology on "Science for Survival" in Washington DC again devoted its attention chiefly to "protein problems". A fair comparison can therefore be drawn and progress can be measured.

It speaks well for the Stockholm meeting if I state that no strikingly new approach or discovery was revealed in Washington, and anybody reading this woll odited book 